\title{
JANKY BÉLA*
}

\section{A témakeretezés hatása a menekültpolitikával kapcsolatos véleményekre}

\section{Bevezetés $^{1}$}

Az alábbi tanulmányban egy 2015-ben és 2016-ban zajlott ún. survey-kísérlet sorozatának eredményeit mutatjuk be. A kísérletekben azt vizsgáltuk, hogy miképpen befolyásolhatja a Magyarországra belépő menedékkérők iránti attitüdöket a menekültválság és a menekültek médiareprezentációja. A médiakeretezés hatását tudatosan egy olyan időszakban vizsgáltuk, amikor a téma a közvélemény érdeklődésének a fókuszába került, és nagy súlya volt a közéleti diskurzusokban.

A menekültválsághoz kapcsolódó események és közpolitikai kérdések egész Európában a figyelem középpontjában voltak az elmúlt két évben. Ez nem meglepő, hiszen Európa régen szembesült hasonló számú menedékkérő koncentrált érkezésével. Továbbá számos menedékkérö, különösen a tengeri útvonalon érkezők, az életüket kockáztatják. Az EU határaihoz közeli humanitárius katasztrófa mértéke is példa nélküli az európaiak többsége számára. Látnunk kell azonban, hogy Európa-szerte ambiciózus politikusok jelentős részben fütötték a diskurzust. A téma központi szerepéhez hozzájárultak a migránsokkal riogató pártok és kormányok. Ugyanakkor a befogadásért demonstratívan kiálló vezető politikusok kommunikációja és lépései is lényegi részét képezték ennek a diskurzusnak.

Magyarország speciális szerepet játszott a menekültválság kezelésében és a kérdés európai diskurzusának alakításában. A 2015-ben az Unióba lépő menedékkérök többsége áthaladt az országon, amely emiatt a figyelem középpontjába került. Ennél lényegesebb, hogy a kormány aktívan reagált az eseményekre. Nemcsak az intézkedések fontosak, hanem azok kommunikációja és az intézkedésektől független aktív kormányzati kommunikáció is. A kormányzat magas rangú képviselői a kezdetektől kiemelt témaként tekintettek a menedékkérők érkezésére, és azt állították, hogy az Unióba irányuló tömeges migráció Magyarország gazdaságát, biztonságát és társadalmi kohézióját fenyegeti. ${ }^{2}$

Ezek az állítások egy olyan ország kormányzatának álláspontját tükrözték, amelyben a bevándorlás nem tartozott a lényegi társadalmi problémák közé, és a közvélemény sem értékelte úgy hogy fontos kérdés lenne. Magyarországon kevés nem európai származású bevándorló él; az itt élő bevándorlók többsége a szomszédos országokból érkezett magyar ajkú és identitású

\footnotetext{
*A szerző az MTA TK Szociológiai Intézetének tudományos főmunkatársa. E-mail: janky.bela@tk.mta.hu

${ }^{1}$ Köszönöm Bognár Adriennek a pilot kutatás kivitelezésében és elemzésében, valamint a 2015-ös kutatás elökészítésében nyújtott segítségét. Köszönöm Kolozsi Ádámnak, az Index.hu tudományos újságírójának tanácsait és segítségét. Köszönöm az Index.hu együttmüködését. Az empirikus felmérések egy részét a K 113208 sz. OTKA kutatás finanszírozta (kutatásvezető: Szakadát István, egüttmüködéséért hálás vagyok). A felméréseket továbbá az MTA TK „Társadalmi konfliktusokra adott identitáspolitikai válaszok” c. „Inkubátor” program támogatta. Köszönettel tartozom Feischmidt Margitnak ezért és tartalmi tanácsaiért.

2 (Bernáth és Messing 2015, Kenyeres és Szabó 2016)
} 
migráns. ${ }^{3}$ Ráadásul a szóban forgó menekültválság során az országba lépő menedékkérők közül sem akart gyakorlatilag senki sem Magyarországon maradni, és a döntő többségük nagyon hamar el is hagyta az országot.

Tekintettel arra, hogy a bevándorlás leginkább virtuális kérdés Magyarországon, különösen nagy volt a sajtó felelössége abban, hogy miképpen tálalja a téma iránt korábban érdeklődést nem mutató, más kontinensről érkezett bevándorlókkal kapcsolatban érdemi személyes tapasztalatot nem szerző közvélemény számára az eseményeket és azok szereplőit. Ugyanakkor a sajtó lehetőségeit erősen korlátozta, hogy a kormányzat komoly erőfeszítéseket tett azért, hogy tematizálja a kérdést. A kiemelt felelősség tehát egyszerre jelentkezett a médiakeretezés komoly korlátaival.

A közvélménykutatásokból tudjuk, hogy a menedékkérők és bevándorlók elfogadottsága és befogadásuk támogatottsága csökkent a válság kitörése óta. ${ }^{4}$ Emellett úgy tünik, hogy a kormányzat válsággal kapcsolatos politikája élvezi a választók többségének támogatását. Ugyanakkor csak sejtéseink vannak arról, hogy különböző tényezők milyen szerepet játszhattak a közvélemény alakításában.

Ebben a tanulmányban azt vizsgáljuk, hogy egyes, a menekültkérdéssel foglalkozó médiatartalmaknak, konkrétan a kérdés keretezésének milyen hatása lehet az adott tartalmat fogyasztó választók preferenciáira egy olyan időszakban, amikor a téma központi helyet foglal el a tömegkommunikációban és a kormányzati kommunikációban. Elemzéseinkben különös figyelmet szentelünk azon választók véleményének és a manipulációkra adott reakcióinak, akik az átlagosnál jelentősen erősebben/gyengébben voltak kitéve a téma kormányzati tematizálásához kötődő információknak.

A médiahatás kísérleteket online kérdőíves felmérésekben, lakossági mintákon végeztük 2015 második felében és 2016 első felében. A kísérletekben a válaszadók egy része egy rövid cikket olvasott a menekültválsággal kapcsolatban, és ezután válaszolt egy (2016-ban három) közpolitikai kérdésre. Mindkét kísérletben volt egy-egy ún. kontroll csoport, melynek tagjai minden előzetes manipuláció nélkül válaszoltak a közpolitikai kérdésekre. Emellett mindkét felmérésben két kísérleti csoport volt (azon válaszadók csoportjai, akik előzetes cikkolvasás után válaszoltak kérdésekre), azaz kétféle cikket olvashattak a válaszadók (értelemszerüen mindenki csak egyet-egyet). A cikkek jellege különbözött a különböző felmérésekben, de az közös volt, hogy az egyes kísérletekben egyik cikk keretezése olyan volt, hogy várakozásaink szerint a menedékkérők iránti szolidaritást növelhette, illetve a menedékkérőknek kedvező közpolitikai megoldások irányába terelhette a véleményeket, míg a másik ezzel ellentétes hatást válthatott ki. Egy diákok körében végzett pilot vizsgálat után összesen három lakossági felmérést végeztünk 2015 decemberében, majd 2016 március-áprilisában, illetve júniusban és júliusban. Ebben a tanulmányban az egymással jól összevethető első és harmadik lakossági vizsgálat eredményeit foglaljuk össze.

${ }^{3}$ (Eurostat 2016)

${ }^{4}$ (Simonovits - Bernát 2016) 
A következő fejezetben ismertetjük a kutatás alapjául szolgáló hipotéziseket. Ezután a felméréseket és az elemzési módszereket mutatjuk be. A negyedik fejezetben prezentáljuk az eredményeket. A kutatásunk tanulságait végül egy rövid összegzésben foglaljuk össze.

\section{A kutatás hipotézisei}

Ez a kísérleti vizsgálat nem képes valóságban lezajló médiadiskurzusok szerteágazó hatásainak egzakt mérésére. Az ilyen jellegü vizsgálatoknak komoly mérési korlátai vannak, bár az utóbbi pár évben ígéretes eredmények születtek ezen a területen. ${ }^{5}$ Kutatásom egyes médiatartalmak témakeretezésének rövidtávon jelentkező befolyásolási képességét méri. Az ilyen típusú vizsgálatoknak az a feltevése, hogy a kísérletileg mérhető hatások fontos elemei a hosszútávon érvényesülö komplex hatásoknak.

Politikai-társadalmi attitüdök kutatásában a keretezés az elit- és médiadiskurzus közvéleményt befolyásoló mechanizmusait jelöli. A kommunikációelmélet a keretezés szük értelmezését kedveli, mely szerint a keretezés arra vonatkozik, hogy egy adott információt hogyan prezentálnak. ${ }^{6}$ A szociológusok körében gyakrabban alkalmazott befogadóbb definíció szerint a keret egy olyan szerveződési elv, narratíva, amely értelmezési keretet ad bizonyos eseményeknek azáltal, hogy a témák és a dilemmák bizonyos aspktusait kiemeli, másokat meg elhallgat. ${ }^{7}$ Ez utóbbit a megkülönböztethetőség céljából téma-keretezésnek nevezzük. ${ }^{8}$

Korábbi kutatások azt mutatják, hogy a témakeretezés érdemben befolyásolja a bevándorlókról és bevándorlásról alkotott. ${ }^{9}$

A fenti kutatások eredményei alapján azt feltételezhetjük, hogy a témakeretezés érdemben befolyásolja a válaszolók menedékkérőkkel kapcsolatos álláspontját. A vizsgált helyzet azonban további szempontok figyelembevételét igényli. Az utóbbi években a téma kutatói arra hívják fel a figyelmet, hogy meghatározó lehet, hogy a kísérletek előtt milyen elözetes keretezési hatásnak lettek kitéve a válaszadók. ${ }^{10}$ A gyakorlatban ezt még kevesen teszik meg. ${ }^{11} \mathrm{Az}$ a néhány vizsgálat, amely szisztematikusan figyelembe vette a kísérlet idején zajló társadalmi diskurzust, azt találta, hogy a kísérletben vizsgált téma előtérbe kerülése esetén a kísérleti hatások lecsökkenhetnek. ${ }^{12}$ A bevándorlás témakörében egy ilyen jellegü kutatást ismerek, Svájcból. ${ }^{13}$

${ }^{5}$ (Fraile és Iyengar 2014, Soroka et al. 2013)

${ }^{6}$ (Scheufele - Iyengar 2012)

7 (Gamson - Modigliani 1987)

${ }^{8}$ Slothuus 2008).

${ }^{9}$ véleményeket (pl. Blinder és Jeannet 2014, Hainmueller és Hopkins 2015, Harell et al. 2012, Igartua and Cheng 2009, Igartua et al. 2011, Iyengar et al. 2013, Ostfeld 2016, Sarrasin et al. 2015, Simonovits 2012, Turper et al. 2015

${ }^{10}$ (Druckman és Leeper 2012)

11 (Einstein és Glick 2015)

12 (Druckman és Leeper 2012, Lecherer et al. 2009) 
A társadalmi kontextus hatását figyelembe vevő kutatások alapján azt várhatjuk, hogy az egyes kísérleti manipulációk hatása legyengül egy olyan időszakban, amikor a téma a közbeszéd középpontjában van. Ez a hipotézis nem csupán a kísérleti módszerről szól, hanem a valós médiatartalmak valós életben gyakorolt befolyásáról egy olyan időszakban, amikor a téma a középpontban van.

Néhány kutatás ugyanakkor a társadalmi kontextus fentinél összetettebb hatását vizsgálja. Bechtel és szerzőtársai kutatása a pártpolitikai orientációkkal interakcióban vizsgálják a kísérleti témakeretezés intenzív közéleti diskurzus idején gyakorolt hatását. ${ }^{14}$ Egy bevándorlással kapcsolatos népszavazás kampányának idején végzett kísérletükben figyelték meg, hogy a téma felhozatala a keretezés jellegétől függetlenül a válaszolók politikai orientációjának megfelelő válaszok gyakoriságát növelte meg.

A kutatásban a témakeretezéssel kapcsolatban a fent bemutatott három közelítést teszteljük.

\section{Adataink és módszereink}

\section{A felmérések}

Az első lakossági felmérést megelőzően, 2015 szeptemberében és októberében pilot vizsgálatot végeztünk 280 budapesti és pécsi egyetemista részvételével. Ennek a pilotnak az eredményeiröl korábban részletesen beszámoltunk. ${ }^{15}$ A lakossági felméréseket a Kutatócentrum Online Piackutató Kft. végezte. Az első lakossági felmérés 2015 decemberében volt, 500 fös, online kvótás mintavétel alapján. A lakossági adatfelvétel mellett kérdőíveztünk diákok körében is, kb. 200 fös mintán, és egy 150 fős felmérést végeztünk Facebook-on toborzott ad hoc mintán. Ez utóbbi két minta adatait az eredmények robusztusság-vizsgálatakor használtuk fel: azt néztük meg, hogy a lakossági minta eredménei reprrodukálhatóak-e más módszerrel vett mintákon (azaz stabilak, robusztusak-e az eredmények, vagy épp ellenkezőleg, érzékenyek a minta és a kérdezés sajátosságaira). A közölt eredmények csak a lakossági mintában kapott válaszokra vonatkoznak, a robusztusságvizsgálatok eredményeire külön hivatkozunk.

Míg a pilot vizsgálat idején az új határrendészeti gyakorlat bevezetése, és az ennek nyomán kialakuló röszkei konfliktus miatt a határátlépőkkel kapcsolatos hírek a közéleti diskurzus középpontjában voltak, a 2015 decemberi vizsgálat egy csendesebb időszakra esett. 2016 júniusában nagyobb, 1000 fős online lakossági mintán ismételtük felmérésünket. A második felmérés is egy (a kormány népszavazási tervei nyomán) intenzívebb diskurzust hozó periódust követő (és a 2016-os népszavazási kampányt megelőző), viszonylag csendesebb időszakban zajlott.

\footnotetext{
${ }^{13}$ (Bechtel et al. 2015)

${ }^{14}$ (Bechtel et al. 2015)

${ }^{15}$ (Bognár \& Janky 2015)
} 


\section{A függö változók, a vinyetták és a kisérleti dizájn}

Mindkét lakossági adatfelvételben az adott időszakban releváns kérdéseket tettünk fel, és az adott időszakban releváns újságcikkekkel kereteztük a kérdés feltevése előtt a menekültproblémát. Az első felmérésben a függő változó a magyar határon legálisan átlépő menedékkérők kívánatos kezelésére vonatkozó kérdés. A második felmérésben, miután megismételtük az első felmérésben feltett policy-kérdést, a válaszadó által kívánatosnak tartott EU hozzáállásáról érdeklődtünk, továbbá a kvótajavaslatról kértük ki a válaszadók véleményét. Tehát ez utóbbi felmérésben több függő változónk is volt.

Az első felmérésben komplex - a mintanagyasághoz képest talán túlzottan is komplex kísérleti dizájnt alkalmaztunk. A hírkeretek mellett manipuláltuk a szóhasználatot és a cikkekhez kapcsolt képeket is (ez utóbbiakról későbbi elemzésekben számolunk be). Az első felmérés tapasztalatai alapján alakítottuk ki a második felmérés kereteit. Egyrészt a pénzügyi lehetőségekkel élve megnöveltük a mintaelemszámot. Másrészt ugyanakkor csökkentettük a kísérleti dizájn komplexitását azzal, hogy nem variáltuk a képi világot. Harmadrészt jelentősen megnöveltük a kontrollcsoport (azon válaszadók csoportja, akiknek nem mutatunk a menekültkérdéssel kapcsolatos híreket, mielőtt policy-kérdéseinket feltennénk) nagyságát. Mindhárom változtatás becsléseink statisztikai erejének növelését szolgálta. 


\section{A menedékkérőkre vonatkozó kérdőív-kérdés}

Mit gondol, mit tegyen a kormány a háborús övezetekböl származó, Magyarország határára legálisan érkező, menedékkérelmet beadó menekültekkel? Kérem, jelölje be azt az állítást, amely a legközelebb áll az Ön véleményéhez!

1- Támogatni kell, hogy új hazára leljenek Magyarországon.

2 - Biztosítani kell a menekülteknek a kulturált szállást, egészséges étkezést, egészségügyi ellátást, ideiglenes munkavállalási lehetőséget és gyerekeiknek az oktatást addig, amíg hazájukban nem rendeződik a helyzet.

3 - Legfeljebb 1-2 hónapos átmeneti időre kell nekik biztosítani egyszerü szállást, étkezést és alapvető egészségügyi ellátást, majd el kell hagyniuk az országot.

4 - Legfeljebb 1-2 hetes átmeneti időre kell nekik biztosítani egyszerü szállást, étkezést és alapvető egészségügyi ellátást, majd el kell hagyniuk az országot.

5 - A túléléshez szükséges segélycsomagot és sürgősségi egészségügyi ellátást kell a menekülteknek biztosítani, és utána azonnal el kell hagyniuk az országot.

6 - Miután regisztrálták a menekülteket, azonnal ki kell toloncolni őket az országból.

9 - Nem tudom.

Elméletileg egyszerünek tünik, hogy egy adott csoport megítélésétől függő közpolitikai preferenciákra ható keretezési hatások vizsgálatakor egy, a csoportot pozitívan bemutató tartalom, és egy, őket negatívan bemutató tartalom közül olvasnak egyet a válaszadók. Azonban számos dimenzió mentén lehet variálni a menekültkérdéssel foglalkozó tartalmakat (is). És egyes aspektusok hatása például függhet attól, hogy tematikus vagy epizodikus keretezésben merül fel; azaz a téma általános leírásakor vagy személyek sorsának bemutatásakor. ${ }^{16}$ Ha legalább a keretezés néhány legfontosabb aspektusának hatását akarjuk szisztematikusan vizsgálni úgy, hogy minden lehetséges manipulációs kombinációt elkülönítünk, nehezen kezelhető számú kísérleti alcsoportra kell osztani a mintát. Egy megoldás lehet egy vagy két apsektus kiválasztása és a vizsgálathoz kiválasztott médiatartalom variálása a szóban forgó egy vagy két aspektus mentén. Egy másik megoldás jelentős keretezési különbségek létrehozása sok fontosnak gondolt dimenzió egyidejü változtatásával.

Van ugyanakkor egy másik dilemma is: a valós médiariportok a kereteket meghatározó elemeket nem feltétlenül valamilyen tiszta elméleti logika mentén tartalmazzák. Ebben a vizsgálatban a fent vázolt elméletileg tiszta megoldások helyett valós cikkek (illetve azokhoz hasonló szövegek) vizsgálatát preferáltuk. Az Index.hu portállal müködtünk együtt. Az első vizsgálatban releváns, de pár hónappal korábban megjelent Index.hu-cikkek rövidített változatait

${ }^{16}$ (Iyengar 1990, Iyengar et al. 2013) 
olvashatták a kezelt csoportokba került válaszadók. A második felmérésben az aktuális hírek alapján állítottam össze fiktív újságcikkeket. Mindezzel együtt lehatárolható a pozitív és negatív hangvételű cikkek közötti alapvető különbség: a pozitív hangvételü cikkek a menekülök motivációira és elszántságára koncentrálnak; míg a negatív hangételủek a menekülők tömeges érkezésével Európára nehezedő nyomást hangsúlyozzák.

Mindegyik, a válaszadók által olvasandó cikk utolsó mondata a figyelemellenőrzést szolgálta, ${ }^{17}$ ami egyben a kérdések figyelmes olvasására történő implicit felhívásnak is tekinthető. ${ }^{18}$ Úgy tünik, felméréseinkben a válaszadók több mint hatvan százaléka nem olvasta végig alaposan a neki kiosztott cikket. Ez a korábbi nemzetközi tapasztalatokhoz képest némileg magasabb arány (Oppenheimer et al. 2009). Ugyanakkor a cikket nem teljesen olvasók egy része is az alapos olvasókhoz hasonlóan reagált az ingerekre.

A fentiekben bemutatott manipulációktól függetlenül (a faktoriális dizájn logikája alapján) minden második kérdőívben menekültként hivatkoztam a határokat átlépő emberekre; míg a többi kérdöívben következetesen bevándorlóként hivatkoztam rájuk. A kontroll csoportokban ez a kérdőív-kérdéseket érintette. A kérdések mellett a cikkek szóhasználatát is a kísérleti ingernek megfelelően egységesítettük: a válaszadók fele olyan cikket olvasott, amely kizárólag menekültként említette az Európába igyekvő embereket, a másik fele pedig olyat, amelyben kizárólag bevándorlóként hivatkoztak rájuk (a cikkek és az utána következő kérdések szóhasználata egymáshoz igazodott).

\section{További változók és a modellek}

A kísérleti manipulációk mellett a magyarázó változók két csoportját különítettük el. Az egyik csoport a válaszadók politikai attitüdjeit méri. Két kérdésre adott válaszok alapján kategorizáltuk a válaszadókat. Fontosnak tartottuk, hogy elválasszuk egymástól a kormánnyal kritikus bal, illetve jobboldali érzelmủ választópolgárokat. A magyarázó változók másik csoportja a médiafogyasztási szokásokra vonatkozó itemeket tartalmaz. A hírfogyasztás mennyiségére vonatkozó kérdések mellett konkrét csatornák és híroldalak híreinek követésére is rákérdeztünk.

A magyarázó változók fenti két csoportja mellett néhány alapvető szocio-demográfiai kontrollváltozó is bekerült az egyébként igen rövid kérdőívekbe. Az alapvető kontrollok mellett rákérdeztünk a külföldi barátokra is.

Vitatott, hogy randomizált kísérletekben érdemes-e többváltozós elemzésekkel kontrollálni például a szociodemográfiai változókra. ${ }^{19}$ Tekintettel arra, hogy kutatásunkban a laboratóriumon kívüli tényezők és ezek önálló vagy a manipulációkkal interakcióban történő befolyásának vizsgálata alapvető, számunkra nem volt kérdés, hogy többváltozós modelleket is kell használni. Ezek eredményeit online mellékletben közöljük.

\footnotetext{
${ }^{17}$ (ld. Oppenheimer et al. 2009)

${ }^{18}$ (Hauser \& Schwarz 2015)

${ }^{19}$ (Freedman 2008, Lin 2013)
} 
A felméréseinkben gyüjtött online kvótás lakossági minták nem tekinthetők olyan valószínüségi mintáknak amelyek alapján minden hezitálás nélkül, a szokásos tesztekkel következtethetünk a populációs paraméterekre. Azonban látni kell, hogy az elmúlt években végzett módszertani kutatások szerint az ilyen típusú mintákból, hasonló jellegü társadalompolitikai kérdések vizsgálatakor a változók közötti összefüggésekre vonatkozó eredmények nagyon hasonlóak a jobb minőségü mintákban mért eredményekhez. ${ }^{20}$ Erre építve elemzéseinkben úgy teszünk, mintha valószínüségi mintáink lennének, és ennek megfelelően használjuk a szokásos statisztikai teszteket.

\section{Az eredmények}

\section{A kísérleti ingerek hatásai}

Korábban már utaltunk rá, hogy a kísérleti médiahatás-vizsgálatok klasszikus feltételezése, hogy közéleti hírek keretezésével befolyásolhatóak a híreket olvasó kísérleti alanyok közpolitikai kérdésekre adott válaszai. Az utóbbi évek kutatásai ugyanakkor arra hívják fel a figyelmet, hogy a laboratóriumon kívüli valós médiatartalmak befolyásoló ereje elnyomhatja a kísérleti inger hatását. Néhány újabb kutatás azonban rámutatott, hogy a valós médiadiskurzus nem feltétlenül nyomja el a kísérleti inger hatását; bizonyos helyzetekben inkább átalakítja azt.

A menedékkérők hosszú távú befogadását (1-es vagy 2-es válaszlehetőség) támogató válaszadók aránya a különböző kísérleti csoportokban (az érvényes válaszok százalékában)

${ }^{20}$ (Weinberg et al. 2014, Mullinix et al. 2015) 


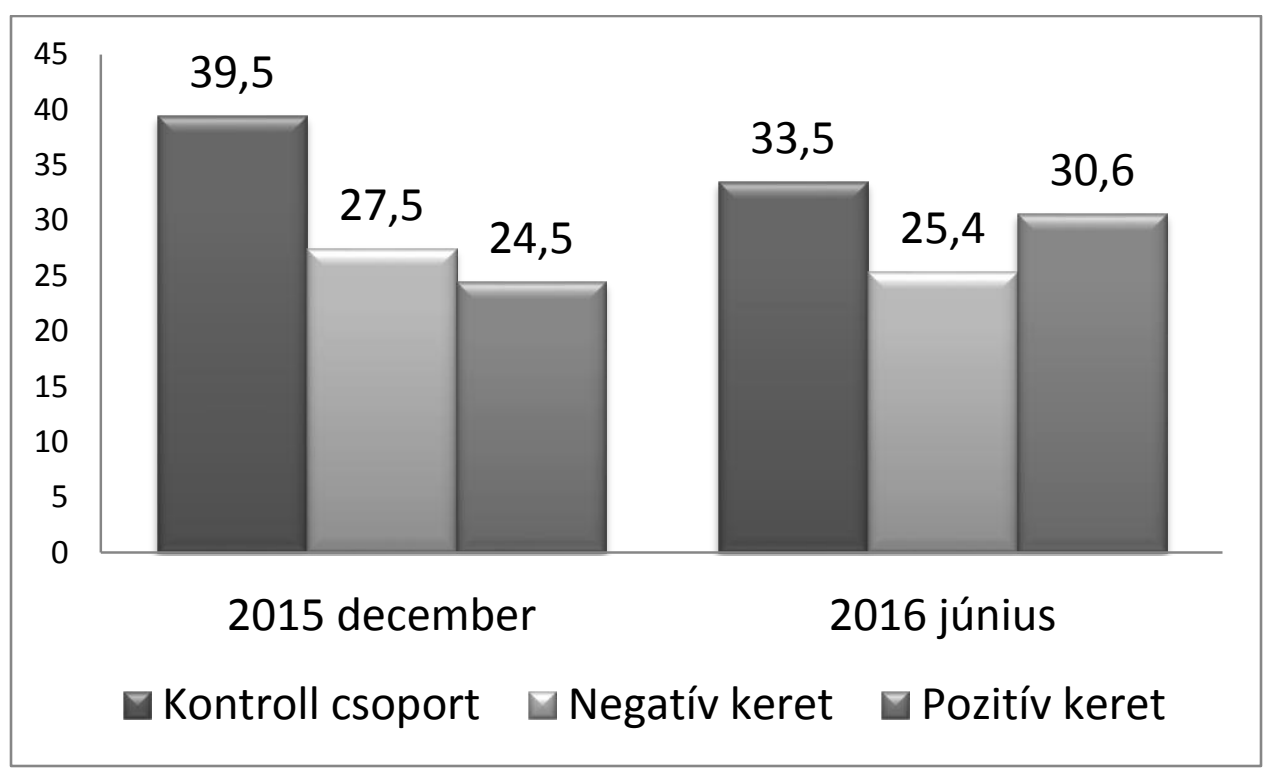

Érvényes válaszok 2015-ben $n=465$; 2016-ban n=938. A 2015-ös mintában a kontroll- és kezelt csoport közötti különbség 3\%-os szinten szignifikáns.

A 2015 decemberében végzett első lakossági felmérés eredményei nem csupán a médiahatás kísérletek klasszikus programjának várakozásait cáfolják, de a kísérleti inger hatásának eltünésére vonatkozó újabb téziseket is. Eredményeink azt mutatják, hogy híreket olvasó (kezelt) csoportban viszonylag jelentősen (és statisztikailag szignifikánsan) eltérő a válaszok megoszlása, mint a kontrollcsoportban. Azonban a menedékkérők hosszabb távú ellátásának támogatottsága mind a pozitív, mind a negatív témakeretet olvasó csoportok körében alacsanyabb, mint a kontrollcsoportban. E negatív hatás mértékében gyakorlatilag nincs különbség a pozitív és a negatív hírkeretek között. Az igaz ugyanakkor, hogy a menekültekkel kapcsolatos hírek prezentálásának hatása kisebb azok között, akik vélhetően alaposan végigolvasták a számukra kiosztott cikket (azaz átmentek a szöveg végén található figyelemteszten).

Az adatok arra utalnak, hogy ebben az időszakban a menekülttéma előhozatala a téma prezentálásától függetlenül hatott a közpolitikai attitüdökre. Azok, akiket 2015 decemberében nem emlékeztettünk a menekültválságra, szolidárisabb menekültpolitikát javasoltak, mint azok, akiknek a témáról valamilyen (bármilyen) anyagot mutattunk.

A 2016 nyarán végzett felmérés adatai is arra utalnak, hogy mind a negatív, mind a pozitív keretezésű hírek prezentálása csökkenti a mendékkérőket segítő intézkedések támogatottságát - kivéve azok között, akik átmentek a pozitív keretezésü cikk utolsó mondatába rejtett figyelemteszten. Ugyanakkor a mintabeli adatok alapján becsült negatív hatás kicsi és statisztikailag nem szignifikáns. Ne feledjük ugyanakkor, hogy a külső környezet változásait követve változtak a válaszadóknak bemutatott cikkek is. Így a két vizsgálat nem tökéletesen összevethetö (akkor sem lenne összevethetö, ha a 2015. decemberi cikkek szerepeltek volna a 2016-os vizsgálatban, mivel akkor 2016 nyarán irreleváns információkra adott reakciókat 
mértünk volna). E korlátokkal együtt is elmondható, hogy az adatok arra utalnak, hogy a menekültekkel kapcsolatos vélemények stabilizálódtak a két felmérés közötti időszakban. A társadalmi háttérváltozók tekintetében ugyanakkor az eredmények többnyire visszaigazolták a természetes várakozásokat. A jobboldali politikai orientációjú és/vagy a jobboldalinak tartott hírcsatornákat követő emberek kevésbé bizonyultak befogadónak, mint a baloldaliak. Az iskolázottabbak befogadóbbak, mint a kevésébé képzettek. A lakóhelynek és az anyagi helyzetnek ellenben nincs jól kimutatható erős hatása a menedékkérőkkel kapcsolatos véleményekre.

\section{Összegzés}

Minden korábbinál nagyobb számú menedékkérő érkezett az Európai Unió határaira 2015-ben és 2016-ban. Nem meglepő, hogy ez a migrációs hullám jelentős médiafigyelmet kapott, és jelentős politikai reakciókat váltott ki néhány országban. Látni kell ugyanakkor, hogy a legtöbb európai polgár életét egyáltalán nem, vagy csak alig érezhetően érintette, hogy nagyszámú nem európai menedékkérő érte el és lépte át a határokat. Ennek ellenére számos választó számára fontos szimbolikus üggyé vált, függetlenül attól, hogy találkozott-e új érkezőkkel - és Magyarország esetében például függetlenül attól, hogy találkozott-e valaha nem európai származású bevándorlóval. A közelmúlt politikai eseményei több országban igazolják azokat a válság alatt felmerült feltételezéseket, miszerint a menekültválságnak nem csupán a menekült- és bevándorláspolitikával kapcsolatos közhangulatra lesz hatása, hanem a pártpolitikai erőviszonyok és a multikulturalizmus népszerüségének alakulására is. Ez alapján a hírtermelők felelőssége e kérdés tárgyalásában még nagyobb volt, mint a legtöbb társadalmi-politikai probléma bemutatásában.

Magyarország speciális eset a menekültválsággal kapcsolatos média- és poltikai diskurzus, továbbá a válságra reagáló kormányzati intézkedések szempontjából. Az Európán kívüli országokból történő bevándorlás virtuális kérdés Magyarországon. A határainkat átlépő menedékkérők olyan gyorsan hagyták el az országot, amilyen gyorsnak csak tudták. Ennek ellenére, a menekültválság, bevándorlási problémaként értelmezve, a közéleti diskurzus első számú témája volt az elmúlt két évben. A magyarországi kutatási adatok extrém körülmények között mutathatják meg a médiakeretezés lehetőségeit és korlátait.

Kutatásomban arra voltam kíváncsi, hogy a menekültválsággal foglalkozó médiatartalmak témakeretezése hogyan befolyásolhatta a médiafogyasztók attitűdjeit egy olyan időszakban, amikor a téma a közéleti diskurzus fókuszában volt, és a kormányzat rendkívül aktívan kommunikált a témában. Médiahatás-vizsgálataink az egyes riportok közvetlen, rövidtávú hatásait tudták kimutatni. Survey-kísérletek sorozatát végeztük el 2015 öszétől 2016 nyaráig. Ebben az elemzésben a 2015 decemberében és a 2016 júniusában végzett online lakossági felmérések tapasztalatairól számoltam be. Ezekben a vizsgálatokban a kezelt csoportokba került 
kérdezettek először egy menekültválsággal kapcsolatos rövid cikket olvashattak el, majd ezután a menedékkérőkkel kapcsolatos politikáról fejthették ki véleményüket.

Adataink azt mutatják, hogy a kérdezettek pártpolitikai és ideológiai orientációja fontos meghatározó tényezője a menedékkérőkkel kapcsolatos politikáról alkotott véleményeknek. Emellett adatbázisainkban erős korrelációt találtunk a politikai orientáció, a médiafogyasztás és a policy-vélemények között (1. az online mellékletet). A kormánypárti és általában az ideológiailag középutas választók attitüdjei különösen erős korrelációt mutatnak médiafogyasztási szokásaikkal, nevezetesen az állami hírtelevízió müsorainak követésével.

Kísérleteink eredményei arra utalnak, hogy az egyes hírtartalmak keretezésének befolyásolási képessége jelentősen korlátozott a jelenlegi magyar kontextusban. Azt találtam, hogy ha egyáltalán kimutatható valamilyen hatása a hírtartalmaknak, az független a hírtartalomban uralkodó témakerettől. Nevezetesen, a téma felvetése az, ami képes befolyásolni a kinyilvánított attitüdöket, és nem az, hogy miképpen prezentálja egy-egy riport a témát. 2015 végi felmérésünkben mind a pozitív, mind a negatív témakeretezésű cikk hatására csökkent a menedékkérők befogadását támogató válaszadók aránya, azaz a hírek olvasását követően a keretezéstől függetlenül nőtt a kormány menekültellenes álláspontját támogatók aránya. Ez az eredmény a politikai elitnek a diskurzust befolyásoló képességére mutat rá, és arra, hogy aktív kormányzati kommunikáció esetén korlátozott lehet a kormányzati szándéktól független hírtartalmak előállítóinak állampolgári véleményekre gyakorolt befolyása. ${ }^{21}$

Kétségtelen, hogy a médiatartalmak befolyásának feltételezett lehetőségeit és korlátait csak akkor tudjuk értékelni, ha olyankor is elvégezzük a fent ismertetett kísérleteinket, amikor ez a téma Magyarországon már egy ideje kikerült a közéleti diskurzus fókuszából. Úgy vélem, hogy erre még sokat kell várnunk.

A regressziós elemzés eredményei és a kísérletekben felhasznált cikkek az alábbi oldalon érhetőek el:

https://drive.google.com/file/d/0B-qpUqAOfZ1pOTJnWXVkUWhYOTA/view?usp=sharing

\section{Hivatkozások}

Bernáth Gábor - Messing Vera: Bedarálva: A menekültekkel kapcsolatos kormányzati kampány és a tőle független megszólalás terepei. In: Médiakutató, 2015, 16. (3.) szám, 7-17.

Bechtel, Michael M. - Hainmueller, Jens - Hangartner, Dominik - Helbling, Marc: (2015). Reality bites: The limits of framing effects for salient and contested policy issues. In: Political Science Research and Methods, 2015, 3. (03.) szám, 683-695.

${ }^{21}$ (v.ö. Bechtel et al. 2015, Druckman and Jacobs 2015) 
Blinder, Scott, - Jeannet, Anne-Marie-.: (2014). Numbers and waves, the illegal and the skilled: the effects of media portrayals of immigrants on public opinion in Britain. Working paper, Prepared for presentation at the Annual Meeting of the American Political Science Association, Washington,DC, August 28-31 2014. Available at SSRN 2476123.

Bognár Adrienn - Janky Béla (2015). Menekült-hírek és véleményalkotás 2015 öszén: Egy médiahatás-vizsgálat első eredményei [News reports on refugees and public opinion in the Autumn of 2015: first results of a media-effect study - In Hungarian]. Socio.hu, 2015(4): 136-150.

Druckman, James - Jacobs, Lawrence: (2015). Who Governs? Presidents, Public Opinion, and Manipulation. Chicago: University of Chicago Press.

Druckman, James - Leeper, Thomas: (2012). Learning more from political communication experiments: Pretreatment and its effects. American Journal of Political Science, 56(4), 875-896.

Einstein, Katherine, - Glick, David : (2015). Cynicism, Conspiracies, and Contemporaneous Conditions Moderating Experimental Treatment Effects. Manuscript, Boston University, Department of Political Science.

Eurostat (2016). Migration and migrant population statistics. In. Statistics Explained. http://ec.europa.eu/eurostat/statistics-

explained/index.php/Migration_and_migrant_population_statistics

Fraile, Marta - Iyengar, Shanto: (2014). Not All News Sources Are Equally Informative A CrossNational Analysis of Political Knowledge in Europe. The International Journal of Press/Politics, 19(3), 275-294.

Freedman, David: (2008). On Regression Adjustments to Experimental Data. Advances in Applied Mathematics, 40(2), 180-193. http://dx.doi.org/ 10.1016/j.aam.2006.12.003

Gamson, William -Modigliani. Andre.: The changing culture of affirmative action. In Research in political sociology. Edited by R. G. Braungart and M. M. Braungart. Greenwich, CT, JAI Press, 1987.

Hainmueller, Jens, - Hopkins, Daniel (2015). The hidden american immigration consensus: A conjoint analysis of attitudes toward immigrants. In: American Journal of Political Science, 2015, 59. (3.), 529-548.

Harell, Allison - Soroka, Stuart, Iyengar, Shanto-Valentino, Nicholas: The impact of economic and cultural cues on support for immigration in Canada and the United States. In: Canadian Journal of Political Science, 2012, 45(03), 499-530.

Hauser, David - Schwarz, Norbert: It's a trap! Instructional Manipulation checks prompt systematic thinking on 'tricky' tasks. In: SAGE Open, 2015, 5(2), 2158244015584617.

Igartua, Juan-José - Cheng, Lifen: Moderating effect of group cue while processing news on immigration. Is the framing effect a heuristic process? In: Journal of Communication, 2009, Vol. 59, No. 4, p. 726-749.

Igartua, Juan-José - Moral-Toranzo, Felix - Fernández, Itziar: Cognitive, attitudinal, and emotional effects of news frame and group cues, on processing news about immigration. In: Journal of Media Psychology, 2011, Vol. 23, No. 4, 174-185.

Iyengar, Shanto: Framing Responsibility for Political Issues: The Case of Poverty. In: Political Behavior. 1990, Vol. 12, 19-40. 
Iyengar, Shanto - Jackman, S. - Messing, S. - Valentino, N. - Aalberg, T. - Duch, R Kobayashi, T. (2013). Do attitudes about immigration predict willingness to admit individual immigrants? A cross-national test of the person-positivity bias. Public Opinion Quarterly 77(3), 641-665.

Kenyeres, Attila Zoltán, - Szabó, József (2016). The migration crisis: representation of a border conflict in Hungarian, German and Pan-European television new coverage. Corvinus Journal of Sociology and Social Policy, 7(1), 71-91.

Lecheler, Sophie - de Vreese, Claes - Slothuus, Rune (2009). Issue importance as a moderator of framing effects. Communication Research, 36(3), 400-425.

Lin, Winston (2013). Agnostic Notes on Regression Adjustments to Experimental Data: Reexamining Freedman's Critique. The Annals of Applied Statistics, 7(1), 295-318. http://dx.doi.org/10.1214/12-AOAS583

Mullinix, Kevin - Leeper, Thomas J. - Druckman, James - Freese, Jeremy (2015). The generalizability of survey experiments. Journal of Experimental Political Science, 2(02), 109-138.

Oppenheimer, Daniel - Meyvis, Tom. - Davidenko, Nicolas: (2009). Instructional manipulation checks: Detecting satisficing to increase statistical power. Journal of Experimental Social Psychology, 45(4), 867-872.

Ostfeld, Mara: (2016). The Backyard Politics of Attitudes Toward Immigration. Political Psychology. Forthcoming. Doi: 10.1111/pops.12314

Sarrasin, Oriane - Fasel, Nicole - Green, Eva - and Helbling, Marc (2015). When sexual threat cues shape attitudes toward immigrants: the role of insecurity and benevolent sexism. Frontiers in psychology, 6: 1033. Doi: 10.3389/fpsyg.2015.01033

Scheufele, Dietram- Iyengar, Shanto.: The state of framing research: A call for new directions. In: The Oxford Handbook of Political Communication Theories. Nueva York: Oxford UniversityPress, Pág, 2012, 1-26.

Simonovits Bori: Ali, Chen, Fatima és Sára esélyei a magyar munkaerő- és lakáspiacon. In: Sik Endre - Simonovits Bori (szerk.): Abena, Sára, Chen és Ali esélyei Magyarországon. Budapest. TÁRKI, 2012, 68-117.

Simonovits Bori - Bernát Anikó eds. (2016). The Social Aspects of the 2015 Migration Crisis in Hungary. Budapest: Tárki Social Research Centre. http://www.tarki.hu/hu/news/2016/kitekint/20160330_refugees.pdf

Slothuus, Rune: More Than Weighting Cognitive Importance: A Dual-Process Model of Issue Framing Effects. In: Political Psychology, 2008, 29. (1.) szám, 1-28.

Soroka, Stuart - Andrew, Blake - Aalberg, Toril - Iyengar, Shanto - Curran, James - Coen, Sharon - Rowe, David: Auntie knows best? Public broadcasters and current affairs knowledge. British Journal of Political Science, 2013, 43. (04.) szám, 719-739.

Turper, Sedef - Iyengar, Shanto - Aarts, Kees - and van Gerven, Minna: (2015). Who is Less Welcome?: The Impact of Individuating Cues on Attitudes towards Immigrants. Journal of ethnic and migration studies, 41(2), 239-259.

Weinberg, Jill - Freese, Jeremy- McElhattan, David: (2014). Comparing Data Characteristics and Results of an Online Factorial Survey between a Population-based and a Crowdsourcerecruited Sample. In: Sociological Science, 1. szám, 292-310. $\underline{\text { http://dx.doi.org/10.15195/v1.a19 }}$ 
